\title{
'Red Hot Gospels of Highbrows': R. A. K. Mason and the demise of Phoenix
}

\author{
Stephen Hamilton
}

Phoenix magazine appeared in two distinct volumes during 1932 and 1933, published by the Auckland University College Literary Society under the editorships respectively of James Bertram and R. A. K. Mason. Its importance lies not so much in its contents as in its bringing together a group of writers who came to occupy the critical and creative centre of New Zealand literature during the middle decades of the twentieth century. In addition to Bertram and Mason, its editorial committee included, among others, Allen Curnow, Blackwood Paul, Jean Alison, Hector Monro, and J. A. W. (Jack) Bennett. No less significant than this role as literary catalyst was the encouragement its production gave to some of our most celebrated printer-typographers-Robert Lowry (printer of Phoenix), Denis Glover, and Ronald Holloway.

The following article reproduces some rarely seen documents from the second year of Phoenix's production, including an article by Eric Cook removed from the first number edited by Mason, Mason's own account of the events which led to the closure of Phoenix, and reproductions from two of the three surviving galley pages prepared for the unpublished fifth issue.

In addition to supplying an outlet for early work by Allen Curnow, Charles Brasch and others of their generation, Phoenix also provided a unique venue for the previously neglected poetry of Ron Mason. Installed in the first issue as Elder Poet to his younger peers, Mason took over editorial control of the little magazine after Bertram's selection as a Rhodes Scholar in late 1932. He immediately ran into strife with almost all those involved, becoming isolated from the majority of his editorial committee and then producing an issue which provoked outrage both within and beyond the College precincts. However, it was apparently not the Literary Society, the Students' Association Executive, the College authorities, nor a censorious press which brought Phoenix to a close, but the flight from Auckland of Bob Lowry, pursued by creditors and soon to 
be effectively declared persona non grata on the campuses of the University of New Zealand.

Mason gave his version of some of the more difficult moments of his editorship in a seven page note accompanying a parcel of Phoenix-related material lodged with the Hocken Library in 1962. In the following transcription from pages two to five of Mason's typescript, accidentals have been silently corrected. Clarifying matter is placed in square brackets.

The printer was Robert Lowry, who had established an old press in the University, with some sort of official approval: on this the whole venture really depended. Ultimately, partly as the result of an abortive affair with one of the girls connected with "Phoenix", partly owing to his general capacity for getting his business embarrassed to an insupportable state, he departed suddenly.

He came to me and said, rather shamedly, that he was leaving. I pointed out that the fifth issue was already in galley form, that, if we could get that out, we might have a chance, the way public support was growing, to establish the journal independently of the University. However, he said he could not face up to things. (He was later to establish a number of presses in Auckland, but, despite his technical ability, has never succeeded in maintaining one in stable form).

There was a persistent rumour that the magazine was suppressed by the authorities. This was not so, but it was hard to deny, without laying Lowry open to suspicion as the man responsible for desertion. In fact, the University authorities showed remarkably little disposition to interfere (though doubtless most were relieved to see the end of us). The reasons, I should say, were these. First, a respect for academic freedom and freedom of speech, even among some who strongly disagreed (the late Prof. William Anderson, for instance). Second, a certain amount of sympathy among more liberal elements. Thirdly the fact that, from the start, we found or drew in quite a measure of outside support, even from the unemployed, who were a powerful factor. Fourthly, Dantonian audacity of policy was, as sometimes happens, perhaps the best guarantee of safety.

The one instance of interference (March 1933) had some amusing aspects.

I may say that the students at the time tended to be more illiberal than the staff. An appeal to them to act as "specials" at the time of the riots found a very wide response-an act of enthusiasm openly scoffed at by some staff members, and, to speak in fairness, later repented by some of the students themselves.

The President of the Students' Association at the time was the Rev. M. G. [Martin] Sullivan, then recently ordained. He was a goodhumoured young man and not illiberal, but he had a career ahead of him....

While the intended fifth [i.e., third] issue of "Phoenix" was in page form, Martin went into the printery, read the proofs and 
demanded that work be stopped. The article he had picked on was Eric Cook's "Groundswell”.

Now this article was actually one that I had been somewhat reluctant to include, as it was a particular mixture of explanation through economics and sexual psychology that I was trying to steer clear of. On the other hand, Eric was self-sacrificing, tireless and utterly devoted to any such radical cause as "Phoenix". I had decided to include "Groundswell" because it was fairly representative of quite a body of opinion, it was well-written and Eric was a man of sterling worth supporting us....

On Lowry's reporting the ban, I protested to Sullivan, pointing out, inter alia, that it seemed manifestly unfair of him to object to one man's opinions appearing on one page when he himself had the privilege of putting his opinions on another page, in an article I had asked him to write (a fact which, perhaps not unjustly, he seemed to consider a piece of machiavellianism on my part). He was firm and obtained the support of his Committee, which could clearly over-rule ours, if it came to a procedural show-down-a fact which, of course, we knew.

We expostulated at due length, but finally the [Students' Association] business manager, A. P. Postlewaite, was sent to see me....

I protested vehemently-rights of free speech, no fair trial, editorial responsibility and the rest of it. "Pos" knew enough not to be drawn into argument, just, a bit unenthusiastically, pointing out he had a job to do. My ace of trumps was that removal of the pages would leave an inexplicable gap in the paging and finally we agreed to settle for our right to insert the explanatory note regarding suppression.

As I had hoped, the mere insertion "made" the issue, so keen was the interest in banning at the time. We also, as culmination, made quite a bit extra by running off copies of "Groundswell" and selling them separately.

From notes lodged herewith, I evidently contemplated an attempt to continue interest in the next issue, though I was not anxious to put too much emphasis on the idea of banning nor provoke an internal University feud.

However, I was saved from any necessity for whipping up an interest by the actions of "N.Z. Truth".

I well remember walking down Queen Street one day and seeing copies of a newspaper folded so as to display, right across the head of the front page, the ugly top of the Auckland University College with flames issuing from it. Immediately I thought to myself "ugh, ugh, I know what this is" and rushed to buy a copy.

Sure enough, the whole front page was devoted to a wild attack on the radical student papers, but with most emphasis on "Phoenix". Such publicity from so widely-circulated a paper not only provided material for the June notes but an assured sale for an increased issue. 
In fact, we had a definite place in the community by this time, and could probably have continued for some time independently, but for the debacle mentioned above.

The general policy was popular. Interest in the Soviet Union, for instance, was not something requiring nurture by a minority. The degree of interest mounted rapidly as people woke up to the fact that "it's not true to say that there is unemployment in every country; there's none in Russia”. There was anger that knowledge had been denied, hunger for information on aspects of such a country. Interest in such matters as the growth of Fascism was also widespread.

"Phoenix" was finding a public among various sections throughout the country. Perhaps the best tribute was the fact that, as gleefully reported by a University office-girl, two very obvious policemen would call in to buy a copy.

Only a few copies of Cook's article have survived. One was found inserted into Jean Bertram's copy of volume two, number one, recently acquired by the Alexander Turnbull Library (qRPrNZ LOWR PHOE 1932) and is reproduced below in facsimile with the permission of the Librarian.

Even after the removal of the article-described by John Weir as 'a peculiar and dense amalgam of economics, sociology and sexual psychology' (33)-Phoenix still aroused the wrath of the College's Professorial Board, especially for Rex Fairburn's poem 'Deserted Farmyard', which the Board regarded as 'offend[ing] against the canons of decency and good taste' (Minutes, 15 May 1933). The response of the popular press was equally condemning, a fact which served to further alienate Mason and Lowry from the bulk of their supposed constituency. The tabloid N.Z. Truth, whose banner headline provides the title for this present article, memorably described Phoenix as comprising 'sneers, jeers, bellicose blasphemies, red rantings and sex-saturated sophistries' (1). (Other student magazines attacked in the article were Glover's Caxton Club Press Oriflamme, produced at Canterbury University College, and Student, edited by Alfred Katz for the Victoria College Free Discussion Club. Both were suppressed by their respective College authorities.)

Although a further issue was produced, it too led to mostly negative reactions. The Students' Association Executive challenged Mason's position as editor on the grounds that he was not an enrolled student. An attempt by the Phoenix committee to pay his fees failed and several committee members resigned. Attempts by John Mulgan and others to curtail Mason's editorial control encouraged him to consider moving the magazine off campus. However, student politics were minor irritations compared to the growing problem of debt surrounding both Phoenix and 
Bob Lowry. Bankruptcy was only avoided by the efforts of Blackwood Paul and other students. Paul negotiated with creditors, securing discounts and refunds sufficient to fully nullify the amount owed by Phoenix. Lowry's personal debt of $£ 85$ was offset by a loan from Paul of $£ 50$ and smaller contributions (effectively donations) from Allen Curnow, G. B. Bertram, Dorothea Mulgan, R. P. Anschutz, Sam Leatham and other supporters.

Mason's disappointment at the failure of Phoenix must have been particularly acute when he considered the three galley pages printed by Lowry for the fifth issue. Also deposited in the Hocken, these are reproduced in part below, with the permission of the Librarian. Being galley pages, their physical dimensions preclude full reproduction though it is hoped that the special nature of these unique documents will be clearly evident.

The first facsimile image comprises the upper half of the galley headed 'Phoenix Eight', being part of an article by Jean Devanny reporting on her visit to the Soviet Union in 1931. The proof marks seen here are in Lowry's hand; others on the lower part of the sheet (not reproduced) may have been added by Mason. (I am grateful to Peter Hughes for the attribution of these proof marks.) Devanny toured the Kazakhstan and Turkestan regions as a guest of the Communist Party after attending the World Congress of the Workers International Relief in Berlin. In her autobiography Point of Departure she recalls how '[i]n six weeks of almost perpetual motion, I took down almost 70,000 words in notes and, in addition, sent back to Australia some articles for the communist and trade union press' (147).

The galley headed 'Phoenix Nine' contains a review by Jean Bell (the pseudonym of Jean Alison) of S. W. Scott's Douglasism or Communism. Alison was a significant supporter of Phoenix from its earliest days, acting as secretary to the editorial committee and otherwise supporting its work. Her poem 'The New People' opened the groundbreaking 1934 Caxton Club Press anthology New Poems, edited by Denis Glover and Ian Milner. Other items on the same galley include: a letter to the editor signed 'E. J. Bror. C. Muller, (Hon. Sec. N.Z.P.U.A.)', promoting the work of the New Zealand People's Universities Association, described by Muller as a 'system of residential rural adult colleges, commonly known as Folk Schools, which originated in Denmark'; a review by Geoffrey Fairburn of a translation of a novel by Karl Boree entitled Summer's Not Over ('Faber \& Faber, 7/-'); and the first part of a scathing review by Geoffrey Fairburn of the 1933 
Brahms Centenary concerts and other musical events. After opening with some derisory comments on the need for such celebrations and giving qualified approval for a performance of an unspecified piano and cello sonata, he proceeds to condemn a concert of lieder and other songs in the following terms:

First, for Mr Dawson. I think I can safely say that this performer, in his three Auckland concerts, gave an unapproachable exhibition of playing down to the public taste-I have never experienced anything quite so thoroughly carried out. I can forgive his rotten French pronunciation, his blundering attempts at lieder, his posturing tomfoolery, his smoke-concert platform manner, his inane seasongs-these are easily forgiven, but items such as Trees and I Travel the Road and similar trash, are an insult to concert-goers; the piece-de-resistance, however, was in my opinion $A$ Race Between a Kangaroo and a Dingo doggerel by R. Kipling (poet of Imperialism) set to noise by $\mathrm{Mr}$ (or is it Sir?) German. It was quite worthless and a waste of bad breath.

The concluding part of Fairburn's review was printed on the third galley sheet, headed 'Phoenix Ten', and is reproduced here in full.

Other papers deposited by Mason indicate a shift in the proposed issue towards a broader cultural focus: they include a review of Nelle Scanlan's Tides of Youth by Hector Monro, offers by J. C. Beaglehole of several poems and 'a little inoffensive essay in Marxian interpretation', and items by Noel Pharazyn (later a major contributor to Tomorrow) and Alfred Katz, editor of the suppressed Victoria University College radical magazine Student. The original objective of Phoenix, as expressed in the first editorial of March 1932, 'to try to establish something of dominion significance', while it had begun to bear fruit from that very issue, would require a further fourteen years before being fully realised in the most significant and long-running of New Zealand's little magazines, Landfall.

\section{WORKS CITED}

Auckland University College. Professorial Board Minutes, 15 May, 1933. University of Auckland: Registrar's Section Archives.

Cook, Eric. 'Groundswell.' Archive of New Zealand Printing, Special Printed Collection, Alexander Turnbull Library, National Library of New Zealand.

Devanny, Jean. Point of Departure. Ed. Carole Ferrier. St Lucia, Qld: University of Queensland Press, 1986. 
Hamilton, Stephen. 'The Risen Bird: Phoenix Magazine, 1932-1933.' Turnbull Library Record 30 (1997): 37-64.

Mason, R. A. K. 'Phoenix file.' MS-0592/o03. Hocken Library, Dunedin.

'N.Z. Universities Hotbeds of Revolution. Red Hot Gospels of Highbrows.' N. Z. Truth 31 May 1933: 1.

Weir, John. R. A. K. Mason. Wellington: Oxford University Press, 1977.

Originally published in Kōtare 1, no. 1 (1998), pp. 5-11. 


\section{GROUNDSWELL}

[A sketch of the chief forces working upon us. I hope to enlarge this in a more detailed strategic survey in later issues. But it is neces. sary that each of us face these problems in the open and work upon them-E.C.]

UNCONTROLLED passions have never failed to vitiate human association on the grand scale. But of all the devil's comedies of history, this Faustian syphilisation of ours is the most sorbid; greed-begotten as it was of the basest of our instincts, we are now about to see its disgusting suicide.

We have driven life frantic, and it has become unmanageable; man faces a new thing-his own life insane and gibbering at him. All across the world our race goes down into the dark, and Fascisms, Marxisms, even Feudalisms again, stretch monstrous powers upon us. The spirit shall escape in the end, but not for two generations at the least, and none may say how deeply it will be marked.

The old unwieldy centres are doomed. But here we have a unique situation-a small isolated unit, inheriting from the western world, but not of it. A little good and much evil is our legacy; a shell of an old life-form that is alien to us; a cadre-a Puritan's corpse already smelling. So we are a reactionary people; we are breeding little Fascists furiously out of our decay. And our Fascism will be of a violently brutal kind, for it will have in it all the sadism of balked desire, the twisted fury of our trapped spirit. It will be masked by economic motives, and will follow the old hate-cleavage of the primitive countryside which feels the town-culture swallowing it whole. But its roots will be sexual. Sex is pivotal.

We are a vigorous people, rigidly selected by a high migration test, heavily sexed in a strange and stimulating climate. Yet we are caught in a vicious thought-system that fears beauty of expression, fresh thinking, singing. We hate creators with the bitter hate of brothers; for we are held in a circle of physical and mental masturbation, and our stirring spirit is sterile. We seem to be asleep, and it is said of us that we are shrewd, but dull of soul. That is true, nor 
do we want to wake; but it is only the asphyxiation of the corpsegases. Communism cannot free us; if it makes the attempt, we shall see the corpse distend and rise, put on fantastic liveliness, and the mad sadism of our young spirit set a Fascist grin on its grotesque face. Decomposition has not gone far enough here for Communism to breed.

What is there then? Are we to suffer for ever in this morgue with our dead thoughts? That decision lies with our youngwhether they are fit to take up life in their hands and love it unfearing. For there can be no fear in this new life we go to live; and no greed. But courage to make joyously and enjoy heartily; and the knowledge that there are no big or little things in ruling, but each must rule-must help-at some point (and must find it) and be ruled otherwhere.

Creation in every form of life is suspect now, hated as the end of safety, feared as the beginning of labour and birth. Yet this is the only release we can look for here-release of the pent splendid force of sex; it is the sole power that can meet the overwhelming reaction that threatens us, for it is capable of an explosion that will blow the corpse into clean air. Each of us - man or woman-has some stirrings of hunger at that thought; it is for each to interpret it, to seek for friends who know that hunger also and are glad. The eating of this bread is not to be feared, for it is life's grood bread that we are starved of ; it is to be used to fuller living, to new creative joy, to a communion. Who will eat with us? Who are our friends?

ERIC COOK 


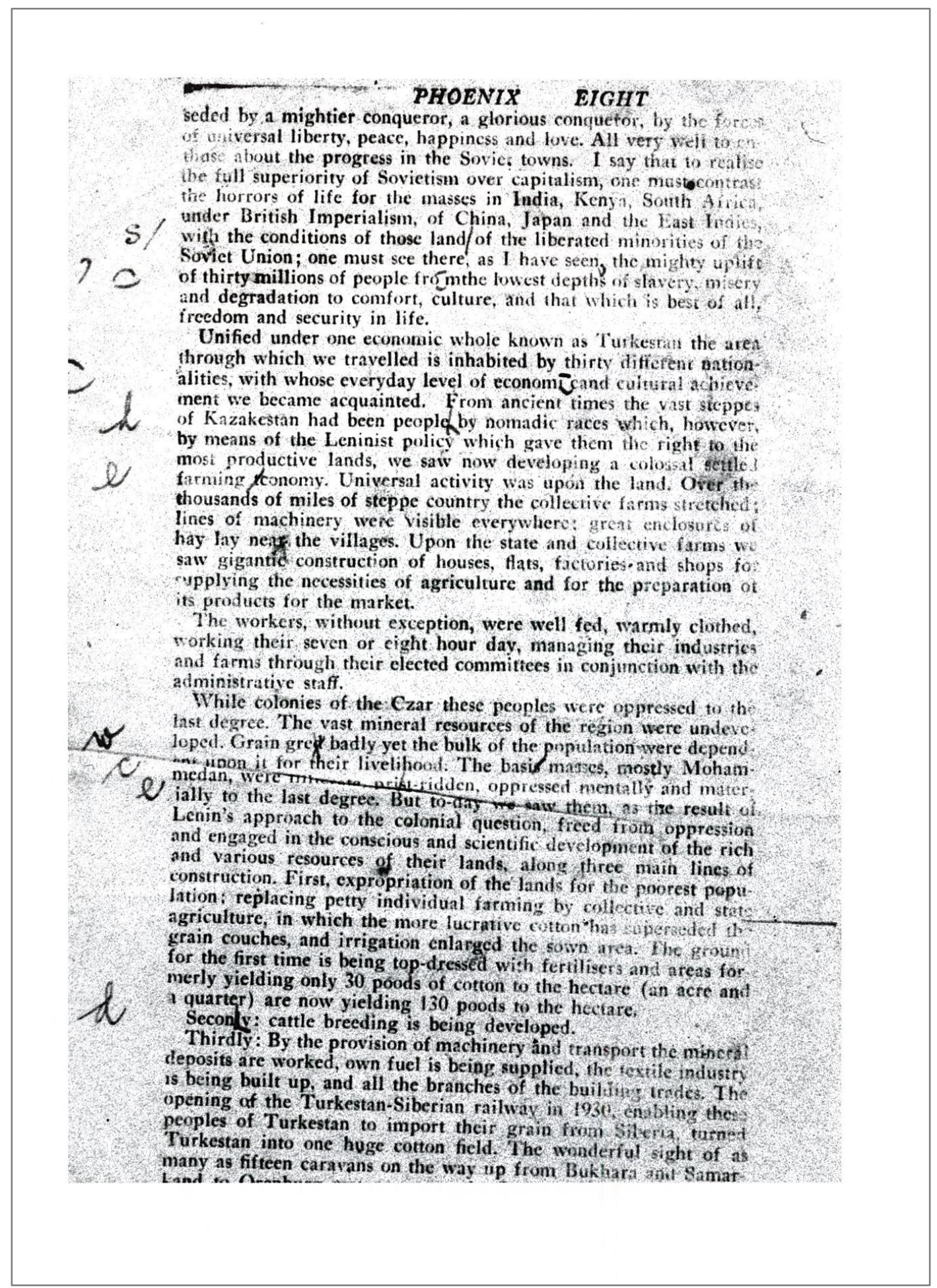




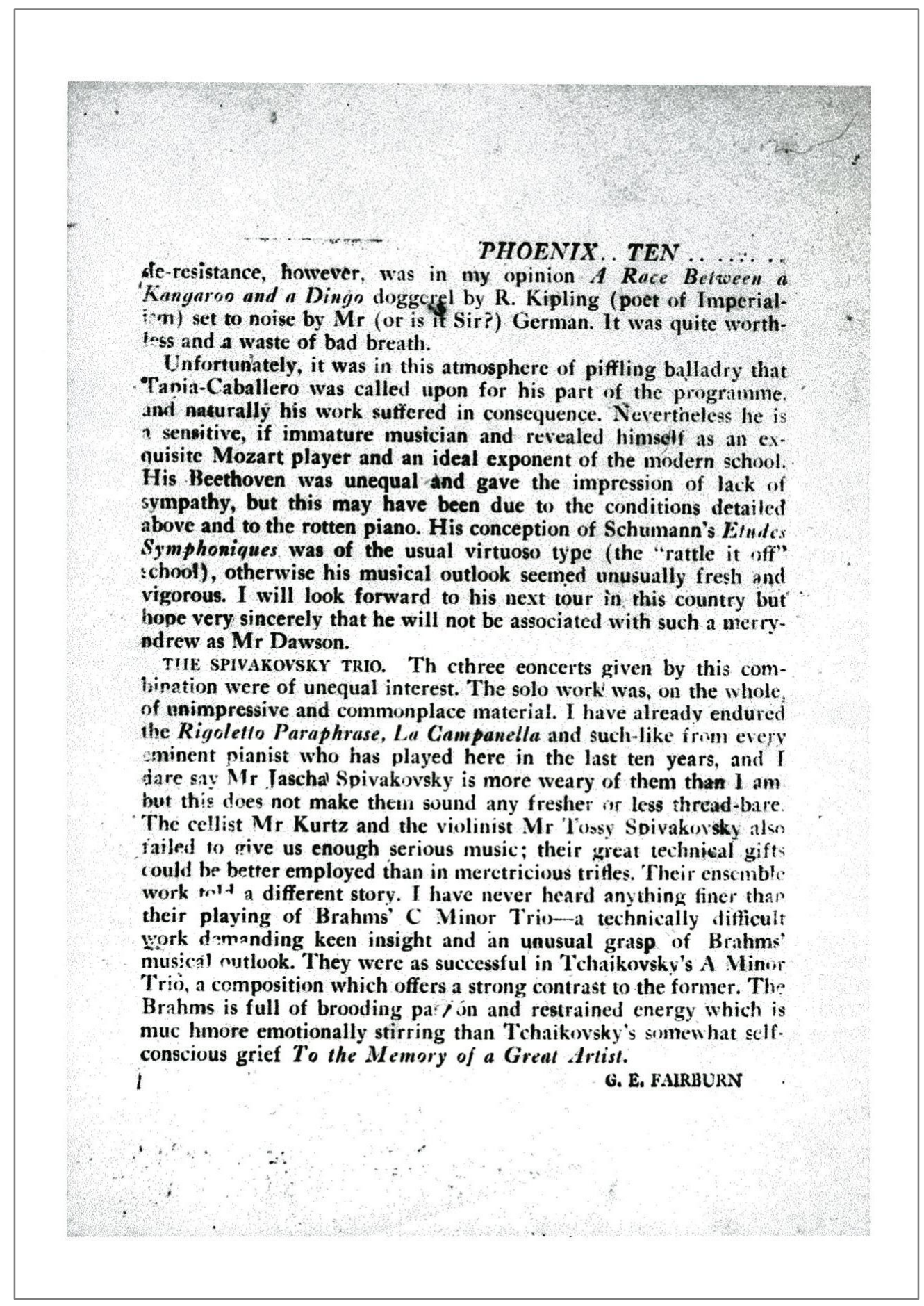

